\title{
Decision Analysis Modeling for Application and Fielding Selection Applied to Concrete Decontamination Technologies
}

\author{
Topical Report \\ August 1, 1995 - October 30, 1996 \\ By: \\ M. A. Ebadian \\ Joseph F. Boudreaux
}

Work Performed Under Contract No.: DE-FG21-95EW55094

For

U.S. Department of Energy

Office of Fossil Energy

Federal Energy Technology Center

P.O. Box 880

Morgantown, West Virginia 26507-0880

\author{
By \\ Florida International University \\ Hemispheric Center for Environmental Technology (HCET) \\ Center for Engineering \& Applied Sciences \\ 10555 West Flagler Street \\ EAS-2100 \\ Miami, Florida 33174
}





\section{Disclaimer}

This report was prepared as an account of work sponsored by an agency of the United States Government. Neither the United States Government nor any agency thereof, nor any of their employees, makes any warranty, express or implied, or assumes any legal liability or responsibility for the accuracy, completeness, or usefulness of any information, apparatus, product, or process disclosed, or represents that its use would not infringe privately owed rights. Reference herein to any specific commercial product, process, or service by trade name, trademark, manufacturer, or otherwise does not necessarily constitute or imply its endorsement, recommendation, or favoring by the United States Government or any agency thereof. The views and opinions of authors expressed herein do not necessarily state or reflect those of the United States Government or any agency thereof. 


\section{DISCLAIMER}

Portions of this document may be illegible in electronic image products. Images are produced from the best available original document. 


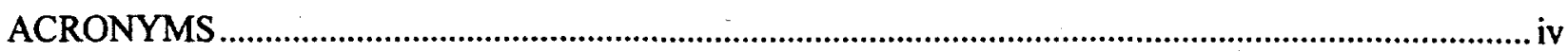

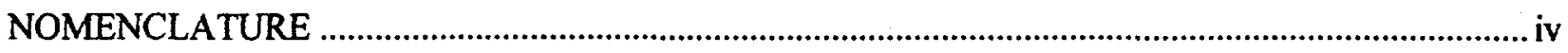

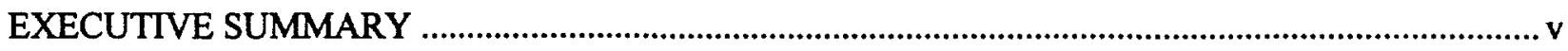

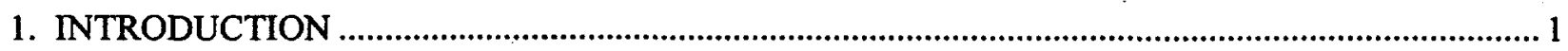

1.1 PURPOSE OF THIS INVESTIGATION …………......................................................

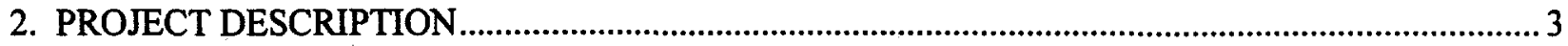

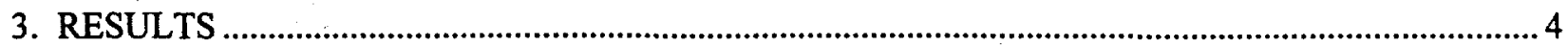

3.1 SURROGATE SELECTION AND PREPARATION …………………………………….... 4

3.2 COMPARING THE END POINTS ACHIEVED TO THE ASSESSMENT

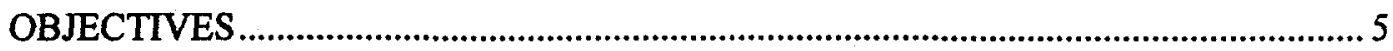

3.3 DETERMINING THE TYPES OF TECHNOLOGIES TO BE TESTED ................................. 5

3.4 TEST LOCATION AND UTILITY PARAMETERS................................................................

3.4.1 Test Equipment, Personnel, and Materials ................................................................ 6

3.5 DATA REQUIREMENTS.........................................................................................

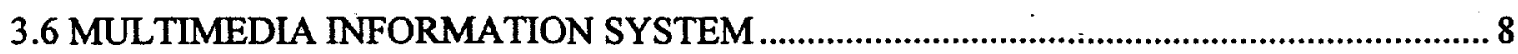

3.7 FIELD TESTING OF INNOVATIVE TECHNOLOGIES ........................................................ 8

4. PLANNED FISCAL YEAR 1997 ACTIVITIES ...................................................................................... 10

4.1 ASSESSMENT DATA REPORTING FORM …………….................................................. 10

4.2 CHARACTERIZATION STUDY, TECHNOLOGY SELECTION, AND SITE SURVEY ANALYSIS .................................................................................. 14

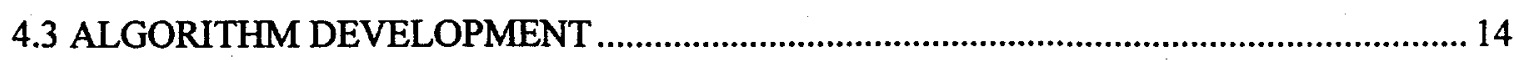

4.4 PROGRAM DEVELOPMENT AND ALGORITHM IMPLEMENTATION .......................... 14

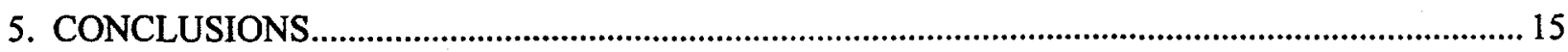

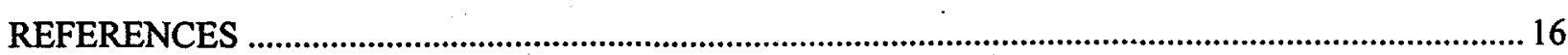




$\begin{array}{ll}\text { D\&D } & \text { Decontamination and Decommissioning } \\ \text { DOE } & \text { Department of Energy } \\ \text { DOE-EM } & \text { Department of Energy - Environmental Management } \\ \text { DOE-OST } & \text { Department of Energy - Office of Science and Technology } \\ \text { FEMP } & \text { Fernald Environmental Management Project } \\ \text { FERMCO } & \text { Fernald Environmental Restoration Management Corporation } \\ \text { FIU } & \text { Florida International University } \\ \text { FIU-HCET } & \text { Florida International University - Hemispheric Center for Environmental } \\ & \text { Technology } \\ \text { FY96 } & \text { Fiscal Year 1996 } \\ \text { FY97 } & \text { Fiscal Year 1997 } \\ \text { HCET } & \text { Hemispheric Center for Environmental Technology } \\ \text { INEL } & \text { Idaho National Engineering Laboratory } \\ \text { IUOE } & \text { International Union of Operating Engineers } \\ \text { MAB } & \text { Michael A. Bruder \& Son } \\ \text { MODM } & \text { Multiobjective Decision Making } \\ \text { ORNL } & \text { Oak Ridge National Laboratory } \\ \text { PC } & \text { Personal Computer } \\ \text { RAPIC } & \text { Remedial Action Program Information Center }\end{array}$

$\begin{array}{ll}\mathrm{psi} & \text { pound per square inch } \\ \mathrm{ml} & \text { milliliter } \\ \mathrm{ft} & \text { foot } \\ \mathrm{V} & \text { volt } \\ \mathrm{amp} & \text { ampere }\end{array}$


The purpose of this two-year investigation is to field test innovative technologies for coating and surface removal on concrete floors and compare the compiled data to baseline technologies, thereby ensuring that the safest and most cost-effective options are developed and subsequently used during the decontamination and decommissioning (D\&D) of U.S. Department of Energy Environmental Management (DOE-EM) sites. Comprehensive and comparable data will be collected in the areas of health and safety, operations, and secondary waste management. The technologies tested will include DOE-EM funded technologies and commercial non-nuclear technologies that have the potential to meet the environmental restoration objectives.

This report summarizes the activities performed during Fiscal Year 1996 (FY96) and describes the planned activities for Fiscal Year 1997 (FY97). Accomplishments for FY96 include the completion of preparatory work to begin field testing of innovative technologies. A total of seven technologies will be tested during FY97. As a part of this project, interactive computer software will be developed during FY97, allowing site-specific parameters and technology performance data to be considered when determining the best option given site-specific conditions. 


\section{INTRODUCTION}

The treatment of radioactively contaminated concrete surfaces is of major concern during the decontamination and decommissioning (D\&D) process. As buildings undergo the D\&D process, concrete floors contaminated with radionuclides such as uranium, cobalt, and technetium-99 must be decontaminated before final disposal. The two primary decontamination objectives for concrete surfaces are: 1) to reduce the potential for personnel and environmental exposure to contaminants during dismantlement and disposal; and 2) the reduction of surface contamination levels to meet the established criteria for unrestricted use.

It is estimated that 23 million cubic meters of concrete will require disposition as 700 buildings undergo the $D \& D$ process. The selection of the appropriate technologies to meet the decontamination objectives for a given site is a difficult process in the absence of comprehensive and comparable data. Choosing the wrong technology could result in increased exposure of personnel to contaminants and an increase in D\&D project costs.

Current technologies used in the decontamination of concrete surfaces are often labor intensive, generate large volumes of secondary waste, and have relatively high operating costs. Innovative technologies are being developed with the goal of providing safer and more cost-effective alternatives that generate less secondary waste, thereby decreasing the treatment costs for contaminated concrete surfaces. During the development and implementation process, performance indicators for the success of these technologies must be reviewed to ensure that these aims are being met. This project provides a mechanism for the assessment of innovative technologies for concrete coating/surface removal.

\subsection{PURPOSE OF THIS INVESTIGATION}

The purpose of this investigation is to field test innovative technologies for the coating/surface removal of concrete surfaces and to compare these results to the baseline technologies. Standardized testing of these new technologies will ensure that the safest and most cost-effective options are being developed for the D\&D of the Department of Energy's (DOE) environmental restoration sites.

Assessments of selected technologies will be conducted under the supervision of the Hemispheric Center for Environmental Technology (HCET) and the International Union of Operating Engineers (IUOE) on the campus of Florida International University (FIU) in Miami, Florida. Comprehensive and comparable data will be collected in the areas of health and safety, operations, and waste management. The technologies tested will include Department of Energy-Environmental Management (DOE-EM) funded technologies as well as commercial non-nuclear technologies that have the potential to meet the decontamination objectives of reducing personnel and environmental exposure or reducing the contamination levels for unrestricted use. Commercially accepted technologies have been evaluated as part of a project funded by DOE-Fernald.

The test conditions developed for the assessment of the innovative technologies is consistent with the baseline testing performed under the contract with DOE-Fernald. The data gathered as part of 
the testing of commercially accepted technologies will be used to compare the performance of the innovative technologies to commercially accepted technologies. This comparison will allow a direct comparison of data related to production rates, health and safety issues, waste generation, and other performance factors.

To facilitate the selection of a given technology, a decision analysis science model will be developed. It will be a computer-based system that will take site-specific data and performance data gathered as part of this study and allow the user to proceed through step-by-step decision process to produce a list of technologies which meet site-specific requirements. 


\section{PROJECT DESCRIPTION}

The two overall project goals for this two-year project are to 1) evaluate innovative technologies and 2) to develop decision analysis interactive computer software.

To facilitate the completion of these two overall project goals, the following tasks have been established:

- Develop a test area to evaluate innovative technologies under conditions found at DOE Complex facilities (completed March 1996);

- Determine technology assessment requirements and a list of potential technologies requiring evaluation (completed February 1996);

- Develop and maintain an electronic data management system (completed August 1996);

- Perform field assessments of two innovative technologies during.FY96 and five innovative technologies during FY97 (scheduled FY96, FY97);

- Document performance results of innovative technologies tested (FY97); and

- Develop interactive computer software which uses the performance data collected and sitespecific data to facilitate the decision-making process in selecting a decontamination technology (FY97). 


\section{RESULTS}

The required preparatory work to facilitate the completion of the field testing of innovative technologies was completed during FY96. These activities included:

- Surrogate selection and preparation;

- Comparing the end point achieved to the assessment objectives;

- Determining the types of technologies to be tested;

- Establishing a test location and utility parameters;

- Data requirements; and

- Multimedia information system.

\subsection{SURROGATE SELECTION AND PREPARATION}

A preliminary review of the types of concrete used at DOE sites indicated a wide variability in the composition of the concrete. This variability made it difficult to choose the proper mix design for the construction of the concrete test areas. To facilitate the testing, a 4000-psi mix was selected to construct the test sections. After the concrete had cured for 30 days, compression tests were performed yielding a concrete compressive strength of $5700 \mathrm{psi}$.

The coating selected was purchased from Michael A. Bruder \& Son (MAB) Architectural and Industrial Coatings. The concrete coating application specifications were to 1) apply Plymastic at 8 $\mathrm{mls}$ wet to obtain $7 \mathrm{mls}$ dry film thickness; and 2) wait 24 hours, and then apply a finish of Plythane 880 coating at $3 \mathrm{mls}$ wet to obtain $1 \frac{1}{2} \mathrm{mls}$ dry film thickness. This coating is consistent with the type of acid resistant coating used throughout the DOE Complex.

Each six-inch-thick concrete slab has an overall size of $20 \mathrm{ft}$. by $40 \mathrm{ft}$. One-half of the test section ( $20 \mathrm{ft}$. by $20 \mathrm{ft}$.) is coated with an aliphatic urethane coating. The other half of the test section consists of uncoated concrete. A six-inch dike surrounds each test section. The six-inch dike allows the technology to be assessed on its ability to remove coating or perform surface removal adjacent to walls. Figure 1 shows one of the test sections that will be used. 


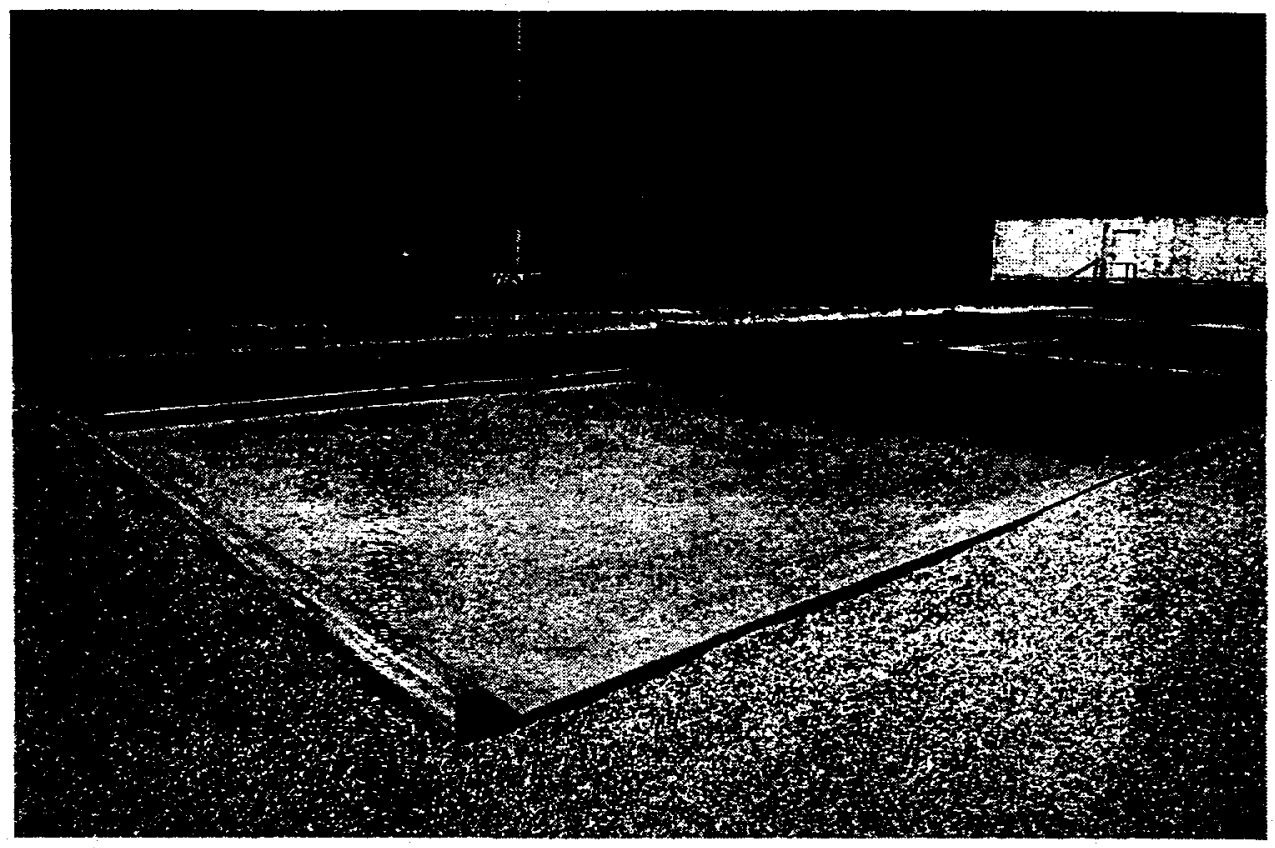

Figure 1. Individual test sections for each technology.

\subsection{COMPARING THE END POINTS ACHIEVED TO THE ASSESSMENT OBJECTIVES}

The end point achieved will be compared to the criteria of 1) coating removal, 2) one-quarter-inch surface removal, and/or 3) one-inch surface removal. To facilitate the determination on the depth of removal, a State of Florida Certified Surveyor performed a 57-point survey of each test area. At the conclusion of the testing, the surveyor will complete a second survey of the same 57 points to determine the depth of removal. The differences between the initial readings and the final readings will be subtracted and averaged over the 57 points to achieve the average depth of removal.

\subsection{DETERMINING THE TYPES OF TECHNOLOGIES TO BE TESTED}

To facilitate the determination of the type of technologies to be tested various publications and databases were reviewed. These publications and databases included:

- DOE/EM-0142P Decommissioning Handbook [1];

- ORNL/M-2751 Oak Ridge National Laboratory Technology Logic Diagram [2];

- EGG-WTD-11104 Idaho National Engineering Laboratory Decontamination and Decommissioning Technology Logic Diagram [3];

- DOE/ORO/2034 Contaminated Concrete: Occurrence and Emerging Technologies for DOE Decontamination [4];

- Operable Unit 3 Treatability Study Work Plan [5]; 
- Remedial Action Program Information Center (RAPIC) database; and

- Operable Unit 3 Remedial Investigation and Feasibility Study Work Plan Addendum, Final [6].

In addition, through interaction with other D\&D professionals and nuclear journals, other potential innovative technologies have been determined. It is anticipated that throughout the second year of this project additional innovative technologies will be identified and reviewed for possible inclusion in the study. The criteria used for inclusion in the testing include state of maturity, cost of the demonstration, potential benefit to the DOE Complex, and availability of the concrete test sections. Established sources and databases were used for categorizing and performing the initial screening of technology types.

To date, the following technologies have been identified for possible inclusion in the study:

- Microwave scabbling;

- Flashlamp;

- Electro-hydraulic scabbling;

- Laser ablation;

- ROVCO2 Pellet System; and

- Liquid Nitrogen with Solid Particles Decontamination System.

\subsection{TEST LOCATION AND UTILITY PARAMETERS}

The test location contains a series of test areas, each consisting of a six-inch thick concrete pad surrounded by a six-inch dike on three sides. Adjacent to the pads is a trailer that serves as a field office, changing facility, and a cool down area for the technologists and the technology assessment team. A fence to restrict access to the area surrounds the trailer and the pads.

The pads are exposed to the environment with one exception. A 20-ft.-by-20-ft. tent with four sides will be erected over half of the concrete pad. This tent will serve as a wind buffer during the collection of dust samples by the International Union of Operating Engineers (IUOE). After the completion of the human factors health and safety portion of the testing, the technologists have the option of using the tent to protect personnel and equipment from the weather conditions.

A 60-psi, six-gallon-per-minute portable water supply and a $110 \mathrm{~V}, 15$ amp electric supply is available for use by the vendors. The vendors will provide any other utilities (e.g., 220 or $480 \mathrm{~V}$ electricity, diesel fuel, compressed air, etc.).

\subsubsection{Test Equipment, Personnel, and Materials}

HCET and the IUOE will supply the following:

- Light duty fork lift;

- Sixty-psi, six-gallon-per-minute portable water supply and a $110 \mathrm{~V} 15$ amp electric supply;

- Surrogate materials; 
- Monitoring instrumentation;

- Project oversight; and

- Sample and data collectors.

The technology vendor is required to supply the following:

- All equipment and support equipment required;

- Trained operators;

- Job safety analysis for each technology;

- Operating procedures;

- Media and other materials;

- Project manager;

- Information required to complete the data requirements section;

- Transportation of all equipment, materials, and personnel to FIU; and

- Per diem for all vendor personnel.

\subsection{DATA REQUIREMENTS}

Extensive data will be collected on each technology. The data will be obtained from vendor contacts and vendor literature. The technologies will be demonstrated to validate the data collected and to collect additional data needed by the DOE project managers. Table 1 presents the data to be collected as part of the assessment process and the sample collection method.

Table 1.

Data Requirements

\begin{tabular}{|c|c|}
\hline Data Requirements & Sample Collection Method \\
\hline \multicolumn{2}{|c|}{ General Information } \\
\hline Technology description & Vendor supplied; field inspection \\
\hline Equipment requirements & Vendor supplied; field verification \\
\hline \multicolumn{2}{|c|}{ Cost Data } \\
\hline Capital cost for the purchase of equipment & Vendor supplied \\
\hline Unit/operating cost & $\begin{array}{l}\text { Vendor supplied; generated from } \\
\text { operational data calculations }\end{array}$ \\
\hline Media cost & Vendor supplied \\
\hline
\end{tabular}


Table 1.

Data Requirements (continued)

\begin{tabular}{|l|l|}
\hline \multicolumn{1}{|c|}{ Data Requirements } & \multicolumn{1}{c|}{ Sample Collection Method } \\
\hline \multicolumn{1}{|c|}{ Operational Data } \\
\hline Production rates & Time studies \\
\hline End point achieved & Use of certified surveyor \\
\hline Labor classification & Vendor supplied; field verification \\
\hline Limitations & Vendor supplied; field inspection \\
\hline Utility requirements & Vendor supplied; field verification \\
\hline Environmental conditions & Vendor supplied; field inspection \\
\hline Secondary waste management & Vendor supplied; field inspection \\
\hline Physical condition of secondary waste & Field observation \\
\hline Quantity of media used & Field calculation \\
\hline Volume of secondary waste & Field calculation \\
\hline Characteristics of media & Media material safety data sheet \\
\hline Equipment portability & Vendor supplied; field verification \\
\hline Operation/maintenance requirements & Vendor supplied, field verification \\
\hline \multicolumn{2}{|c|}{ Implementation Data } \\
\hline Level of training required & Vendor supplied \\
\hline Availability of equipment and supplies & Vendor supplied; verification \\
\hline Health and safety concerns & Vendor and IUOE supplied \\
\hline
\end{tabular}

\subsection{MULTIMEDIA INFORMATION SYSTEM}

The multimedia information system to support decontamination activities provides a means of accessing data related to operation and maintenance, cost and performance data, health and safety, and secondary waste management in the form of an interactive computer-based system. The information system also provides video clips and photographs of the technologies assessed.

To date, the information related to the baseline technologies has been entered into the information system. As the innovative technologies are tested the data gathered as part of these evaluations will be entered into the information system. The intent is to gather all applicable data on previously completed technology assessments and input the data into the information system to ensure that all known technologies are being compared. This system of consolidated information on both the baseline and innovative technologies will allow a complete and comprehensive comparison of technologies during the technology selection process.

\subsection{FIELD TESTING OF INNOVATIVE TECHNOLOGIES}

The activities planned for FY96 included the evaluation of two innovative technologies and the development of a test report detailing the test results. No innovative technologies were tested 
during FY96. The innovative technologies anticipated to be ready for FY96 encountered project difficulties, which pushed back the completion of the assessment process to FY97. Two nonnuclear technologies were reviewed for possible inclusion in the study. However, these technologies were also in the developmental stage and not ready for field testing. Therefore, the goal of field testing two innovative/non-nuclear technologies was not achieved. 


\section{PLANNED FISCAL YEAR 1997 ACTIVITIES}

The activities planned for FY97 include the field testing of seven innovative technologies for concrete coating removal and concrete surface removal and the development of an interactive computer software for decision analysis.

\subsection{ASSESSMENT DATA REPORTING FORM}

Table 2 presents the Assessment Data Reporting Form, which will be completed as part of the field assessment activities.

Table 2.

Assessment Data Reporting Form

\begin{tabular}{|l|l|}
\hline Technology Name: & \\
\hline Class: & \\
\hline Decontamination & \\
\hline Method: & \\
\hline Vendor Name: & \\
\hline Basic Equipment & \\
\hline Support Equipment \\
Description:
\end{tabular}


Table 2.

Assessment Data Reporting Form (continued)

\begin{tabular}{|l|l|}
\hline Removal Capabilities: & \\
\hline Applicable Media: & \\
\hline $\begin{array}{l}\text { Secondary Waste } \\
\text { Characteristics: }\end{array}$ & \\
\hline $\begin{array}{l}\text { Basic System Capital } \\
\text { Cost: }\end{array}$ & \\
\hline Support Equipment: & \\
\hline $\begin{array}{l}\text { Support Equipment } \\
\text { Cost: }\end{array}$ & \\
\hline Removal Media Cost: & \\
\hline Utility Requirements: & \\
\hline $\begin{array}{l}\text { Operation/ } \\
\text { Maintenance } \\
\text { Requirements: }\end{array}$ & \\
\hline Unit Operating Cost: & \\
\hline Maintenance Cost: & \\
\hline $\begin{array}{l}\text { Number of Equipment } \\
\text { Operators: }\end{array}$ & \\
\hline Number of Laborers: & \\
\hline Availability: & \\
\hline
\end{tabular}


Table 2.

Assessment Data Reporting Form (continued)

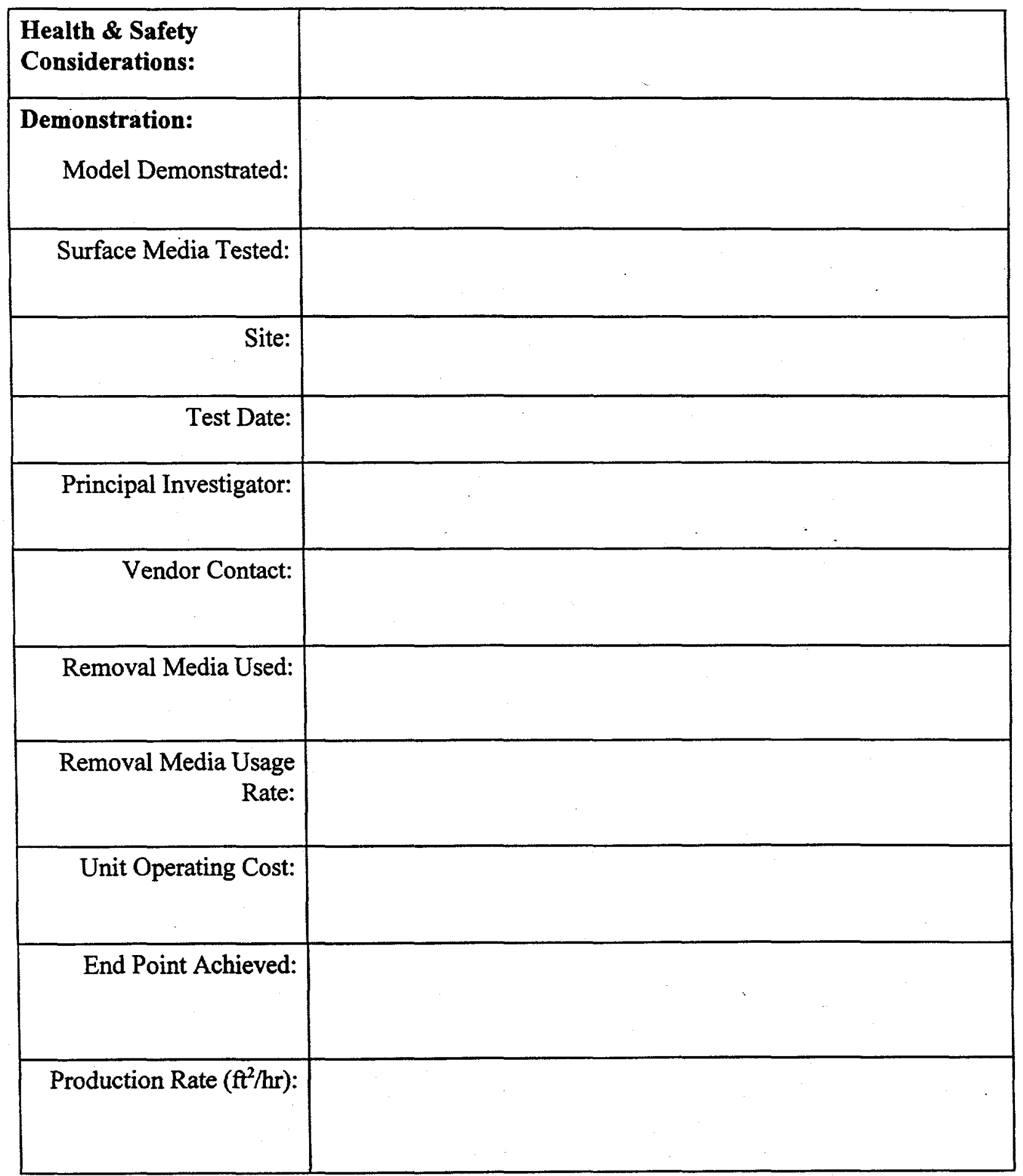


Table 2.

Assessment Data Reporting Form (continued)

\begin{tabular}{|r|r|}
\hline $\begin{array}{r}\text { Volume of Primary } \\
\left(\mathrm{ft}^{3} / \mathrm{hr}\right):\end{array}$ & \\
\hline Wolume of Secondary & \\
$\left(\mathrm{ft}^{3} / \mathrm{hr}\right):$ & \\
\hline Secondary Waste & \\
Characteristics: & \\
\hline Assessment/ Comments: & \\
\hline Peferences: & \\
\hline Publications: & \\
\hline & \\
\hline
\end{tabular}

Multiobjective or multicriteria decision-making techniques (MODM) will be employed to identify the appropriateness of the innovative techniques for surface removal. In order to determine the nature of and achieve the correct weight of the decision variables, $D \& D$ professionals at various sites will be surveyed. A full set of outcome variables will be assigned, and the appropriate technique for algorithm development will be selected. A decision model with 
which to validate the application of given technologies on a site-by-site basis will be developed. In order for the dynamic multi-objective decision problem to be solved on a continuing basis, an interactive or quasi-interactive solution method is anticipated. This method will be applied as the basis for an interactive computer program to solve for appropriateness in the decision-making process for the application of these remediation techniques.

The following three sub-tasks have been defined to complete the development of the interactive computer program that will be used during the selection process of decontamination technologies. These tasks include:

- Characterization study, technology selection and site survey analysis;

- Algorithm development; and

- Program development and algorithm implementation.

\subsection{CHARACTERIZATION STUDY, TECHNOLOGY SELECTION, AND SITE SURVEY ANALYSIS}

Several root documents are required for the initial development of the utility algorithm. Among these are waste form characterization studies, disposal and separation criteria guidelines for waste materials, and results from technology demonstration projects that identify the relative suitability and applicability constraints of various decontamination techniques. Additionally, this analysis will review site survey documents to assign value to the site-specific hazards and risks encountered. An extensive review, in association with DOE oversight, is anticipated to make the appropriate subjective evaluation of the multiple objective decision criteria.

\subsection{ALGORITHM DEVELOPMENT}

Based on the development of the characterization study and the utilization of on-site hazard and risk evaluation, an algorithm will be developed to facilitate informed analysis and decisionmaking for the application of methods previously identified as candidate technologies.

\subsection{PROGRAM DEVELOPMENT AND ALGORITHM IMPLEMENTATION}

An interactive personal computer-based program will be developed to facilitate "what if" studies based on the variance of the objective criteria and the mix of technologies applied to a given site. In order to yield maximum utility, this program will provide the end user with the capability to update the evaluation of the decision variables interactively and to analyze consequences in terms of the optimized resultant value of the outcome variables. Documentation will be developed and provided to facilitate application of the program and allow further development of the algorithm. 


\section{CONCLUSIONS}

The preliminary activities needed to begin the evaluation of innovative technologies are complete. These activities include preparing the test site, developing the performance indicators, and soliciting innovative technology vendors for inclusion in the study. Second-year activities will generate the bulk of the deliverables for this project. The evaluation of seven innovative technologies and the development and implementation of an interactive computer program to facilitate the decision-making process for technology selection will be performed during FY97. 
Fernald Environmental Restoration Management Corporation (FERMCO), 1994, Operable Unit 3 Treatability Study Work Plan, FERMCO, Cincinnati, Ohio.

Fernald Environmental Restoration Management Corporation (FERMCO), 1993, Operable Unit 3 Remedial Investigation and Feasibility Study Work Plan Addendum, Final, U.S. Department of Energy, Cincinnati, Ohio.

Idaho National Engineering Laboratory (INEL), January 1994, Idaho National Engineering Laboratory Decontamination and Decommissioning Technology Logic Diagrams, U.S. DOE, EGG-WTb-11104, EG\&G Idaho, Inc., Idaho Falls, Idaho.

Oak Ridge National Laboratory (ORNL), 1993, Oak Ridge National Laboratory Technology Logic Diagram, ORNL/M-2752, U.S. Department of Energy, Oak Ridge, Tennessee.

U.S. Department of Energy, 1994, Decommissioning Handbook, DOE/EM-0142P.

U.S. Department of Energy, 1990, Radiation Protection of the Public and the Environment, DOE Order 5400.5, Office of Environment, Safety and Health, Washington, DC. 